\title{
Field Measurements Of Sediment Transport Processes In STRATAFORM: Extended Duration Observations
}

\author{
R.W. Sternberg \\ A.S. Ogston \\ University of Washington \\ School of Oceanography \\ Box 357940 \\ Seattle, WA 98195-7940 \\ phone: (206) 543-0589 fax: (206) 543-6073 email: rws@ ocean.washington.edu \\ Award Number: N00014-95-1-0418 \\ http://www.ocean.washington.edu
}

\section{LONG-TERM GOAL}

The long-term goal of the sediment dynamics component of STRATAFORM is to link sediment transport processes on the continental shelf and slope to the formation and preservation of event beds in sediment deposits.

\section{OBJECTIVES}

Our objective is to investigate sediment dispersal mechanisms on the continental shelf and slope. We have maintained long-term monitoring instrumentation in support of these investigations. In particular, the data obtained address the specific topics:

- temporal variability (intra- and inter-annual) of sediment flux on the continental shelf and slope,

- spatial variability (along- and across- shelf) of sediment flux on the continental shelf,

- relationship between the spatial variability of sediment flux and the accumulation rates of sediment on the shelf,

- existence and dynamics of fluid mud on temperate shelves, and

- delivery of suspended sediment to the continental slope and the formation of bottom and intermediate nepheloid layers.

\section{APPROACH}

A shelf tripod in $60 \mathrm{~m}$ water depth (S60) and a slope mooring in $450 \mathrm{~m}$ (Y450) have just completed their fourth year of data collection. Measurements of near-bed currents and suspended sediment have been supplemented by box coring over the 4-year period. This long time-series data set is valuable for: analysis of inter-annual and seasonal transport patterns, establishing the dynamics of resuspension and transport over a variety of storm and flood conditions, evaluation river discharge effects on transport mechanisms, and validation of circulation and sediment transport models. Extended duration observations at S60 also support the plume study and rapid response sampling, including observations to track the increases of nearbed suspended sediment, and net flow directions of nearbed fluid mud layers during storm and flood events, and the correlation of the mud layers to strata development. The current and suspended sediment instrumentation from the Y450 subsurface mooring supplemented by CTD-Transmissometer profiling provides data on the magnitude and mechanisms of particulate 


\section{Report Documentation Page}

Form Approved

OMB No. 0704-0188

Public reporting burden for the collection of information is estimated to average 1 hour per response, including the time for reviewing instructions, searching existing data sources, gathering and maintaining the data needed, and completing and reviewing the collection of information Send comments regarding this burden estimate or any other aspect of this collection of information,

including suggestions for reducing this burden, to Washington Headquarters Services, Directorate for Information Operations and Reports, 1215 Jefferson Davis Highway, Suite 1204, Arlington

VA 22202-4302 Respondents should be aware that notwithstanding any other provision of law, no person shall be subject to a penalty for failing to comply with a collection of information if it

does not display a currently valid OMB control number

\begin{tabular}{|c|c|c|}
\hline $\begin{array}{l}\text { 1. REPORT DATE } \\
\text { 30 SEP } 1999\end{array}$ & 2. REPORT TYPE & $\begin{array}{l}\text { 3. DATES COVERED } \\
\text { 00-00-1999 to 00-00-1999 }\end{array}$ \\
\hline \multirow{3}{*}{\multicolumn{2}{|c|}{$\begin{array}{l}\text { 4. TITLE AND SUBTITLE } \\
\text { Field Measurements Of Sediment Transport Processes In } \\
\text { STRATAFORM: Extended Duration Observations }\end{array}$}} & 5a. CONTRACT NUMBER \\
\hline & & 5b. GRANT NUMBER \\
\hline & & 5c. PROGRAM ELEMENT NUMBER \\
\hline \multirow{3}{*}{\multicolumn{2}{|c|}{ 6. AUTHOR(S) }} & 5d. PROJECT NUMBER \\
\hline & & 5e. TASK NUMBER \\
\hline & & 5f. WORK UNIT NUMBER \\
\hline \multicolumn{2}{|c|}{$\begin{array}{l}\text { 7. PERFORMING ORGANIZATION NAME(S) AND ADDRESS(ES) } \\
\text { University of Washington,School of Oceanography,Seattle,WA,98195 }\end{array}$} & $\begin{array}{l}\text { 8. PERFORMING ORGANIZATION } \\
\text { REPORT NUMBER }\end{array}$ \\
\hline \multirow{2}{*}{\multicolumn{2}{|c|}{ 9. SPONSORING/MONITORING AGENCY NAME(S) AND ADDRESS(ES) }} & 10. SPONSOR/MONITOR'S ACRONYM(S) \\
\hline & & $\begin{array}{l}\text { 11. SPONSOR/MONITOR'S REPORT } \\
\text { NUMBER(S) }\end{array}$ \\
\hline
\end{tabular}

12. DISTRIBUTION/AVAILABILITY STATEMENT

Approved for public release; distribution unlimited

13. SUPPLEMENTARY NOTES

14. ABSTRACT

15. SUBJECT TERMS

16. SECURITY CLASSIFICATION OF:

\begin{tabular}{c|c|c}
$\begin{array}{c}\text { a REPORT } \\
\text { unclassified }\end{array}$ & $\begin{array}{c}\text { b ABSTRACT } \\
\text { unclassified }\end{array}$ & $\begin{array}{c}\text { c THIS PAGE } \\
\text { unclassified }\end{array}$
\end{tabular}

17. LIMITATION OF ABSTRACT

Same as

Report (SAR)

\begin{tabular}{l|l}
$\begin{array}{c}\text { 18. NUMBER } \\
\text { OF PAGES } \\
\mathbf{5}\end{array}$ & 19a. NAME OF \\
& \\
&
\end{tabular}


transport to the slope, and transport off the slope in the form of bottom and intermediate nepheloid layers.

\section{WORK COMPLETED}

Maintenance of the S60 tripod and Y450 mooring has continued in the past year providing a near continuous time-series of current, wave, and suspended sediment concentration data at the two locations. Salvage efforts for the previously deployed O250 mooring (trawled by fishing activity) were partially successful, retrieving a current meter/sediment trap/acoustic release chain for additional mooring work this winter (99/00). The additional mooring has recently been placed in the head of the Eel Canyon (A250) and site selection for an additional tripod to be placed in the entrant channels to the canyon has been accomplished. CTD-Transmissometer surveys were continued in this past year, investigating seasonal changes in internal nepheloid layer structure.

\section{RESULTS}

The four years of current, wave, and suspended sediment data have been preliminarily compiled, and the results illustrate the significant temporal variability, both inter-annual and intra-annual, of sediment flux on the northern California continental shelf. Both the river discharge hydrograph and the atmospheric forcing varies inter-annually, and the last four years of data obtained includes an 80-year flood, and both El Nino and La Nina forcing. The across and along-shelf components of cumulative sediment flux over the four year record are shown in Fig. 1. In both components, the largest net changes are observed in the winter period (Jan-Mar), and occur as a response to episodic events (i.e. the largest storms and river discharge events provide the largest net transport). In the across-shelf direction, the flux is directed seaward during all four winters, whereas, in the along-shelf direction the flux direction differs between winters, with the resulting net transport over the four years being near zero. The tripod arrays (across-shelf in 95/96 and alongshelf in 96/97) provided data to examine the relationship between the spatial variation of sediment flux and longer term sediment accumulation rates. Over the winter deployment periods, in the across and along-shelf directions, there was a convergence of sediment flux between tripod locations. This flux convergence is co-located with the area of highest accumulation rates (Sommerfield and Nittrouer, 1999), i.e., between 60 and $70 \mathrm{~m}$ water depth, and between the K and $\mathrm{S}$ transect lines.

Variability in currents and sediment flux both temporally and spatially may be attributed to complex circulation on the shelf and slope in the study area. We are presently interacting with physical oceanographic modelers at Oregon State University (Julie Pullen/John Allen) who are using nested circulation models in the study area to assist in explaining the variability. Models show the existence of eddy formation (previously observed in satellite photography; Walsh and Nittrouer, 1999) which may be attributed to flow separation around Cape Mendocino during wind reversals associated with typical winter storm systems on this coastline. Presently, we are providing data to validate the models, while modelers are simulating the period of the 80-year recurrence interval flood both with and without the river discharge to evaluate the impact of the plume on shelf circulation, and the resulting pattern of sediment flux.

The observation of a thin layer of extremely high concentration suspended sediments (fluid mud) following the 80-year recurrence interval flood has been a focus of the shelf tripod data analysis. The net sediment flux during the single 3-day event was two orders of magnitude larger than any other event during the winter. A conceptual model has been proposed in which river plume sediment are 


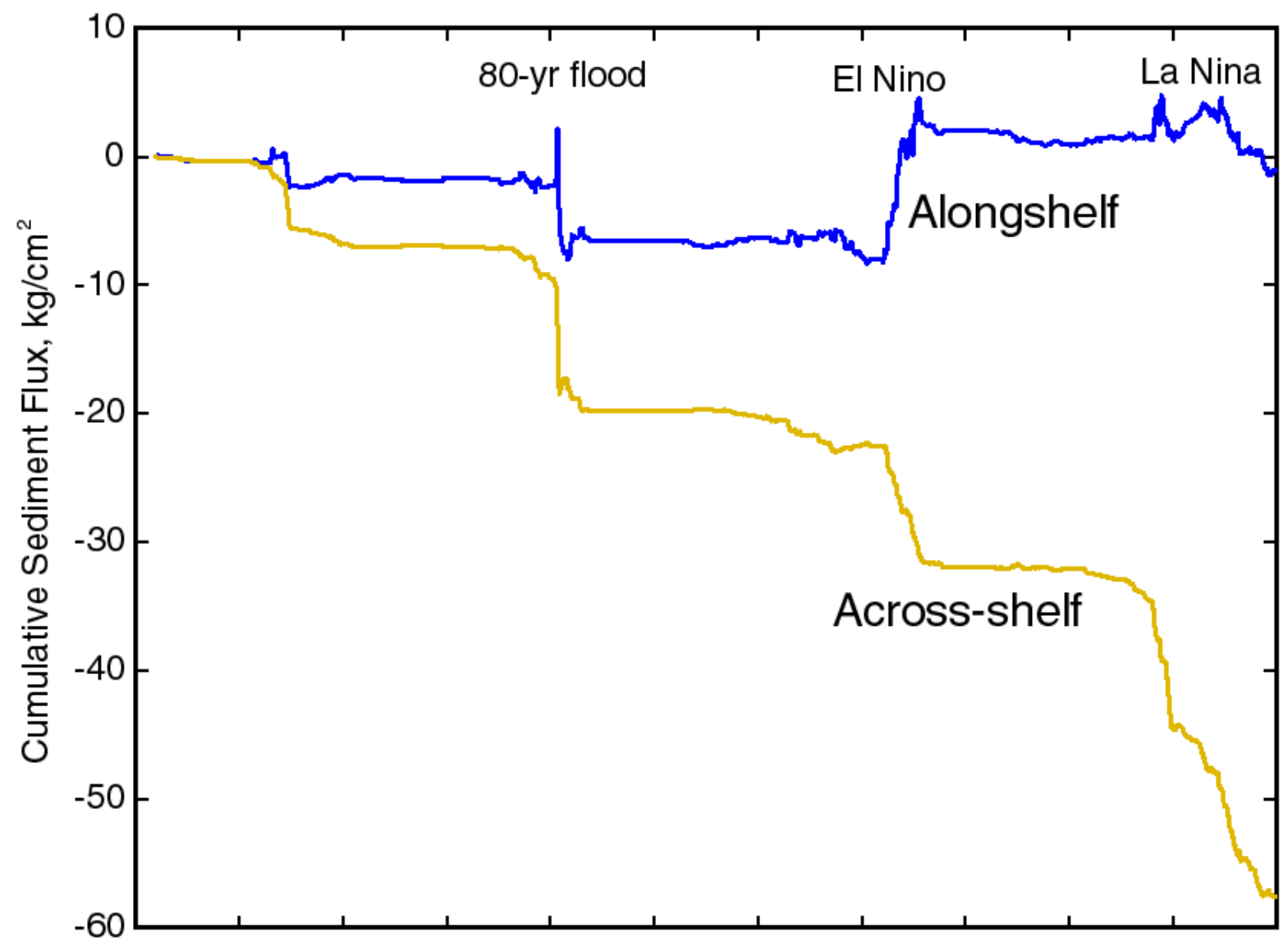

Sep1 Jan1 May1 Sep1 Jan1 May1 Sep1 Jan1 May1 Sep1 Jan1 May1

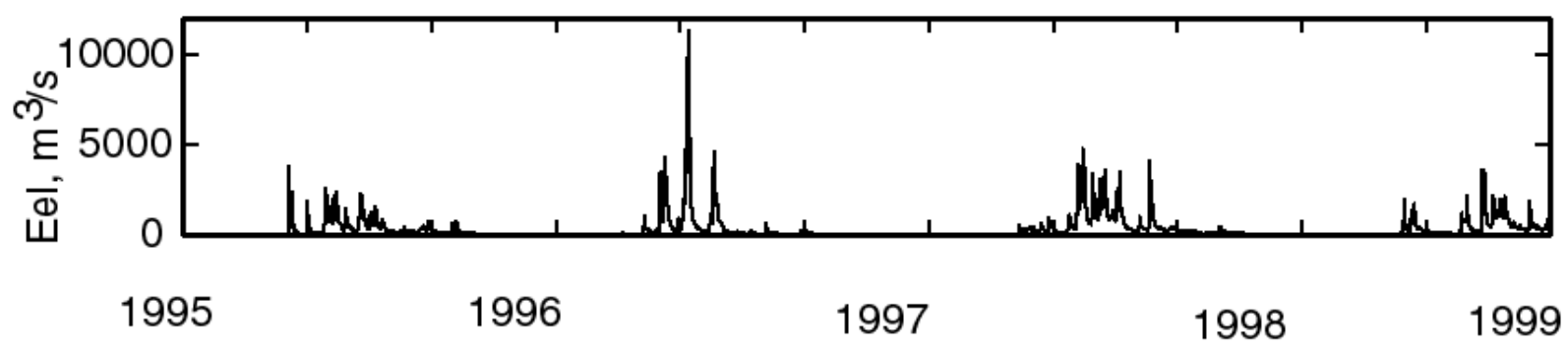

Figure 1. Cumulative sediment flux, along and across-shelf components, and Eel River discharge for the four year period of record at S60. The four winters exhibit distinctly different character in both the river discharge hydrograph and atmospheric forcing which is reflected in the net sediment flux magnitude and direction.

trapped on the inner shelf either due to a weak front or the rapid input of sediment from a confined plume, and form a thin layer of fluid mud. The fluid mud is subsequently transported seaward due to gravitational forcing on the densified fluid, providing a pathway for sediment between the surface plume and the observed flood deposit. 
The CTD-Transmissometer surveys show the geographic and seasonal distribution of intermediate nepheloid layers. Results show that intermediate nepheloid layers are a persistent phenomenon in this area, strongest near and in the Eel River Canyon. Current and temperature measurements obtained from the slope mooring (Y450) reveal energetic tidal and higher frequency internal waves. Results from laboratory experiments have investigated internal wave mixing on sloping boundaries and the generation of isopycnal intrusions from the boundary layer, perhaps a mechanism for intermediate nepheloid layer formation. We are continuing to study the internal tidal dynamics for both slope sedimentation and the generation of bottom and intermediate nepheloid layers over the slope. Also, an additional subsurface mooring has been placed in the head of the Eel Canyon this winter (99/00) to investigate intermediate nepheloid layer development and the sediment dispersal in the canyon.

\section{IMPACT/APPLICATION}

The observed temporal variability of sediment flux supports the need for long-term monitoring of shelf and slope processes to evaluate sediment dispersal mechanisms. The finding of fluid mud on the Eel shelf suggests that our view of temperate shelf processes and resulting sediment transport have been too restrictive.

\section{REFERENCES}

Sommerfield, C.K. and C.A. Nittrouer, 1999. Modern accumulation rates and a sediment budget for the Eel shelf: a flood-dominated depositional environment, Marine Geology, vol. 154.

Walsh, J.P. and C.A. Nittrouer, 1999. Observations of sediment flux to the Eel continental slope, northern California, Marine Geology, vol. 154.

\section{PUBLICATIONS}

Ogston, A.S., D.A. Cacchione, R.W. Sternberg and G.C. Kineke, submitted. Storm and river flooddriven sediment transport on the northern California continental shelf. Flood sedimentation special volume, Continental Shelf Research.

\section{Abstracts}

Cacchione, D.A., L. Pratson and A.S. Ogston, "Internal Tides, Sedimentation, and Seafloor Slopes", AGU 2000 Ocean Sciences Meeting, San Antonio.

McPhee, E.E., "Laboratory Experiments on Internal Wave Generation of Boundary-Layer Intrusions and Nepheloid Layer Detachment”, AGU 2000 Ocean Sciences Meeting, San Antonio.

Mullenbach, B.L, C.A. Nittrouer, and E.E. McPhee, "The Importance of Intermediate Nepheloid Layers in Sediment Export to the Eel Continental Slope", AGU 2000 Ocean Sciences Meeting, San Antonio.

Ogston, A.S., D.A. Cacchione, J. Pullen and R.W. Sternberg, 2000, "Physical and sediment transport observations and modeling on the northern California shelf during storm and flood events", AGU 2000 Ocean Sciences Meeting, San Antonio. 
Cacchione, D.A., A.S. Ogston, E.E. McPhee, R.W. Sternberg and G.B. Tate, 1998, "Internal Tides and Sedimentation on the continental slope off northern California", AGU 1998 Fall Meeting, San Francisco.

McPhee, E.E. and D.A. Cacchione, 1998, "Regional characteristics of suspended sediments at intermediate slope depths on the northern California continental slope", AGU 1998 Fall Meeting, San Francisco.

Ogston, A.S., D.A. Cacchione and R.W. Sternberg, 1998, "River flood sediment flux, flux convergence and shelf circulation on the northern California shelf", AGU 1998 Fall Meeting, San Francisco.

Varela Guerra, J., R.W. Sternberg, and A. S. Ogston, 1998, “Annual variability on mean currents and sediment transport on the Eel River shelf during flood periods", AGU 1998 Fall Meeting, San Francisco. 